\title{
EDUCATING SOUTH AFRICAN LEGAL PRACTITIONERS: COMBINING TRANSFORMATIVE LEGAL EDUCATION WITH UBUNTU
}

\author{
Radley Henrico*
}

The most important motive for work in school and in life is pleasure in work, pleasure in its result, and in the knowledge of the value of the result to the community.

The legal education of future legal practitioners must transcend the normative principles of law. Transformative legal education (TLE) demands that legal pedagogy extends to creating awareness of the importance of transformative constitutionalism which is a means by which social justice can be realized in the South African constitutional dispensation. Moreover, such awareness must be combined with ubuntu (a realization of our humanness and need to help the less privileged). Invoking TLE and ubuntu is a means of ensuring that future legal practitioners may be responsible agents of social change. It is also a means of ensuring that future legal practitioners who hold public office will be suitable incumbents of positions of trust. Administrative law is used, as an example, in which TLE and ubuntu conspire in contributing to transformative constitutionalism and ensuring the realization of social justice in South Africa.

INTRODUCTION

I. THE IMPERATIVES OF TRANSFORMATIVE LEGAL EDUCATION AND UBUNTU

II. EARMARKING LEGAL PRACTITIONERS AS POTENTIAL CANDIDATES FOR PUBLIC OFFICE ......................................................................... 826

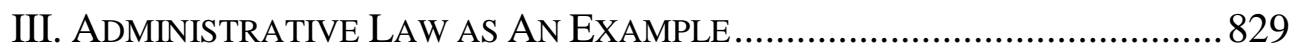

CONCLUSION ........................................................................... 838

\section{INTRODUCTION}

Humankind's social, political, economic and legal advancement is

\footnotetext{
* Senior Lecturer, Department of Public and Procedural Law, Faculty of Law, University of Johannesburg. Research fields: Transformative Legal Education, Social Justice, Ubuntu, Administrative Law, Transformative Constitutionalism, Rule of Law. This paper is an expanded version of a paper delivered by the author at the 5th International Conference on Law, Policy and Regulation in Singapore on 30 May 2016.

${ }^{1}$ Attributed to Albert Einstein in Fiore D., InTROduction to EdUCATIONAL Administration: Standards, Theories and Practice 200 (2nd ed., New York: Eye on Education, 2009); See Ackroyd D., THE History of England Volume 1 Foundation 325 (United Kingdom: Macmillan, 2011) for comments on development of education in the fourteenth century at Oxford and Cambridge.
} 
attributed to the endeavors of various role-players, not least of which are our legal practitioners, their educators and public officials. ${ }^{2}$ Legal graduates who pursue paths in practice, academia, adjudication, or public service must draw on that which they were exposed in their legal education. In this article the author argues that educating future legal practitioners at South African universities cannot simply be about normative principles of law. There is a clamant need to seek a greater purpose and goal. The author argues for a transformative legal education (TLE) approach to education. In addition, such an approach must be suffused with a notion of ubuntu for purposes of the realization of social justice. This is especially true and relevant for a country like South Africa. Formerly a social, political and legal authoritarian system based on a rule by law; now a democratic dispensation committed to change. It is argued that the realization of social justice by means of a comity between TLE and ubuntu is necessary to advance the interests of the less privileged, the marginalised and generally assist others who would not otherwise have a voice or opportunity. This article does not purport to suggest that the approach utilizing TLE and ubuntu is a panacea of pedagogy for legal education. The contention advanced, however, is that TLE and ubuntu renders future legal practitioners responsible agents for change and potential suitable candidates for public office. Finally, administrative law, as an exemplar of public law, and the facts of specific cases are drawn on to illustrate the manner in which such an approach to legal education galvanize the purpose sought to be achieved, namely the advancement of social justice and underscoring the importance of public office responsibilities.

\section{THE IMPERATIVES OF TRANSFORMATIVE LEGAL EDUCATION AND UBUNTU}

The study of every law module essentially consists of understanding the body of rules ${ }^{3}$ governing conduct ${ }^{4}$ applicable to subject matter. To understand is also the result of a mental process a student undergoes by receiving information imparted through various mediums. ${ }^{5}$ Taking music for example: It consists of a collection of tones, which when arranged in a particular order and sequence provides the learner with melodies and

\footnotetext{
${ }^{2}$ See Milonakis D. \& Fine B., From Political Economy to Economics: Method, the Social and Historical IN THE Evolution OF ECONOMIC THEORY (USA \& Canada: Routledge 2009); Glendon M., The Rule of Law in the Universal Declaration of Human Rights, 1 NORTHWESTERN JOURNAL OF HUMAN RIGHTS 11(2004).

${ }^{3}$ Informed by legislation, regulations, case law and constitutional law imperatives.

${ }^{4}$ On the part of a natural or juristic person.

${ }^{5}$ Such as speech, written material, visual or aural observation and tactile communication.
} 
harmonies in accordance specific musical keys or genres. ${ }^{6}$ Whatever facts are observed and assimilated makes more sense especially when arranged and presented in an orderly and didactic manner. ${ }^{7}$ Pedagogy as it relates to legal education in South African is unique on account of the historical socio-political and economic landscape of our country. The result thereof is the culmination of various complexities, not least of which are language, institutional racial tensions, first generation students and a law curriculum that has been the subject matter of extensive debate. ${ }^{8}$ There is no universal one shoe fits all approach to the way in which law modules are lectured in South African universities. ${ }^{9}$ In point of fact any argument that advocates a singular approach is likely to brook debate concerning a violation of academic freedom. ${ }^{10}$

Apart from knowledge being the product of what a student is exposed to, it is also coloured by factors such as methodology, content and intellectual capacity. ${ }^{11}$ Glibly stated, law is the study of rules governing conduct of natural or corporate persons. ${ }^{12}$ Within the realm of academic discourse, law has been conceived as a discipline of the

\footnotetext{
${ }^{6}$ SChOles P., The OXFORd COMPANION TO MuSic 441-452, 619-624 (10th ed. United Kingdom: Oxford University Press, 1970); For the instrumental role music has played in politics see Le RouxKemp A., Struggle Music: South African Politics in Song, 8(2) LAW AND Humanities 247, 249—251 (2014).

${ }^{7}$ Whether we do so consciously or inadvertently. See Lewenstein B., The Meaning of "Public Understanding of Science" in the United States after World War II, 1 Public UndERSTANDING OF SCIENCE 45 (1992); and Berkmanas T., The Development of the Philosophies of Science and Law: Parallelisms, Reciprocities, Perspectives, 2 JuRISPRUdENCE 95-97 (2009).

${ }^{8}$ See Kennedy D., Legal Education as Training for Higher Hierarchy, 31 JLE 591(1982); Robus D. \& McLeod C., White Excellence and Black Failure: The Reproduction of Racialised Higher Education in Everyday Talk, 36(3) SOUTH AFRICAN JouRnal OF PSYCHOLOGY 463-467 (2006); Van Niekerk C., The Four Year Undergraduate LLB: Where to from Here?, OвITER 533, 535-537 (2013); and Greenbaum L., The Four Year LLB Graduate Degree: Progress and Pitfalls, 35(1) JournaL FOR JURIDICAL SCIENCE 12-14 (2010).

${ }^{9}$ For further reading in this regard see Quinot G. \& Greenbaum L., The Contours of Pedagogy of Law in South Africa, STELL LR 29-30 (2015); and Bezuidenhout I. \& Karels M., Legal Educators-The Peddler of Precedent, the Skill Builder and the Socially Conscious Knowledge Generator, 3 ACTA ACADEMICA 40-44 (2014).

${ }^{10}$ Kori E., Challenges to Academic Freedom and Institutional Autonomy in South African Universities, VI (1) INTERNATIONAL JOURNAL OF TEACHING AND EDUCATION 45, 51-52 (2016); and Van Pletzen J., The Implications of Current Legislative Changes for Academic Freedom and Institutional Autonomy of South African Higher Education Institutions, 70-71 (unpublished LLM thesis, University of the Free State 2015).

${ }^{11}$ See Boeglin J. \& Campbell J., Effects of Learners' Readiness on Their Perceived Learning Outcomes, 28(2) CANADIAN JouRnAl OF LEARNING AND TECHNOLOGY 200-202 (2002); Richardson J., Mature Students in Higher Education: Academic Performance and Intellectual Capacity, 28(3) Higher EduCATION Journal 373-374 (1994); and Randi J. \& Corno L., Teacher and Learner Variation, 1 THe British Psychological SOCIETY 47, 54 (2005).

${ }^{12}$ On the evolutionary role of law, culture and hegemony see Merry S., Law, Culture and Cultural Appropriation, 10(2) Yale Journal of LaW \& Humanities 574, 601—603 (2013).
} 
humanities. ${ }^{13}$ However, the dynamic matrix of law and its interplay with morally charged imperatives also positions it in the realm of social sciences. ${ }^{14}$ At its bare essential it is concerned with rules: Seen more holistically, the multi-disciplinary and moral nature of law makes it undeniably vexed and always subject to debate. ${ }^{15} \mathrm{~A}$ study of private or public law necessitates an understanding of various theories upon which legal principles are premised, sustained and informed-commonly referred to as the philosophical aspect of law, namely jurisprudence. ${ }^{16}$

Since 1945 human rights awareness became a focal area on the agenda of legal discourse. ${ }^{17}$ South Africa's involvement in the establishment of the League of Nations served as a paradox against its future role as pariah of western democratic countries on account of its apartheid regime. ${ }^{18}$ An

\footnotetext{
${ }^{13}$ Van Marle K., Regstudie, Die Geesteswetenskappe En Enkele Gedagtes Rondom Regtigheid, 52(4) Tydskrif vir Geesteswetenskappe 749-753 (2012).

${ }^{14}$ Balkin J. \& Levinson S., Law and the Humanities: An Uneasy Relationship, 18(2) YALE JouRnAL of LAW \& the Humanities 154-160 (2013); Siems M. \& Mac Sithigh D., Mapping Legal Research, 71(3) Cambridge Law Journal 651-652 (2012); Priest G., Social Science Theory and Legal Education: The Law School as University, 1 Journal OF LEgAl EdUCATION 436, 438- 439 (1983); and Rublin A., The Role of Social Science in Judicial Decision Making: How Gay Rights Advocates Can Learn from Integration and Capital Punishment Case Law, 19 DUKE JournAL OF GENDER LAW \& PoliCY 179, 182-185 (2011).

${ }^{15}$ In other words that full account is taken of all factors, namely moral, economic and social to give impetus to an informed value-laden decision. See Holmes, The Path of the Law, HARVARD LR 457 (1897); Kok A., The Promotion of Equality and Prevention of Unfair Discrimination Act 4 of 2000: Court-Driven or Legislative-Driven Social Transformation?, 1 STELL LR 89 (2008).

${ }^{16}$ SCOTt J., The Law of COMmerce In SOUth Africa 6 (2nd ed. Cape Town: Oxford University Press 2009); VAn Roermund B., Legal Thought And Philosophy: What Legal Scholarship Is ABOUT 2 - 4 (3rd ed. United Kingdom: Edward Elgar Publishing 2013); Twining W., GeNERAL JuRISPRUdenCE Understanding LAW FROM A Global PERSPECTIVE 253 (London: Cambridge University Press 2009); Bodog M., Legal Theory and Legal Doctrinal Scholarship, 2 CANADIAN JOURNAL OF LAW \& JURISPRUDENCE 483, 490-494 (2010); and Hacker D., Law and Society Jurisprudence, 96 CORNELL LAW REVIEW 727, 729, 737-741 (2011).

${ }^{17}$ Mc Crudden C., Human Dignity and Judicial Interpretation of Human Rights, 19(4) THE European Journal of InTERnational Law 655, 662-663 (2008); Besson S., Human Rights and Democracy in a Global Context: Decoupling and Recoupling, 4 Journal OF EthiCs \& GLOBAL Politics 19, 27-28 (2011); Dodoo V., The Demand for Human Rights in a Diverse Socio-Cultural World Society: Approaches and Tools, 4 Journal OF Politics \& LAW 162-164 (2011); and Mutua M., Standard Setting in Human Rights: Critique and Prognosis, 29 Human Rights Quarterly 547, 552-554 (2007).

${ }^{18}$ Dugard J., The Judicial Process, Positivism and Civil Liberty, 88 SALJ 181 (1971); Dugard J., Human Rights and the South African Legal Order (United States: Princeton University 1978); S v. Makwanyane, SA 391 (CC) para 262,1995(3); Brink v. Kitshoff, SA 197 (CC) where at para 40, 1996 (4); O' Regan J. refers to the systemic discrimination against black people under the apartheid regime; Forsyth C., The Sleep of Reason: Security Cases before the Appellate Division, 105 SALJ 679-680 (1988); and generally LobHam M., White Man's Justice: South AfRICAN Political Trials IN THE Black Consciousness ERA (New York: Oxford University Press 1996); and CoRder H., Judges at Work: The Role AND AtTItUdes of the South AfRicAn APPellate Judiciary 1910-1954 (Cape Town: Juta 1984).
} 
introduction of a democratic dispensation in South Africa held the promise of protection of human rights against the exercise of power. Closely aligned thereto is the notion of transformation from a former authoritarian system to one in which human rights must be respected and realised and thereby attain social justice. ${ }^{19}$ The need for change through a process of transformation became a necessary consequence of the historical context which came to define our common law, as captured in the dictum:

[It] evolved from an ancient society in which slavery was lawful ... Furthermore, apartheid laws and practices permeated and to some extent delegitimised much of the pre-1994 South African legal system. Courts have a duty to develop the common law ... [in accordance with] the Bill of Rights. ${ }^{20}$

Our legal system "provides the rules within which the state's administration, the business world, individuals and organisations-indeed the whole community-operate". ${ }^{21}$ This system, however, is subject to the Constitution of the Republic of South Africa ${ }^{22}$ (the Constitution). These aspirations would prove to be elusive unless, as previously stated, they could be realized. It is precisely here where the education of legal practitioners has a crucial role to play. ${ }^{23}$ A sine qua non of such education is the substantive provisions of the Constitution: A normative concept.

\footnotetext{
${ }^{19}$ Klare K., Legal Culture and Transformative Constitutionalism, 14 SAJHR 146 (1998); Van Marle K., Transformative Constitutionalism as/and Critique, 202 STELLENBOSCH LAW REvIEW 286, 288 289 (2009); Davis D. \& Klare K., Transformative Constitutionalism and the Common and Customary Law, 26 SAJHR 403, 408-412 (2010); Christiansen E., Transformative Constitutionalism in South Africa: Creative Uses of Constitutional Court Authority to Advance Substantive Justice, 13 THE Journal of Gender, RACE \& Justice 575, 581-591 (2010); Also see Honore A., Social Justice, 2 MCGILL LAW JOURNAL 77 (1962), and further authority below on social justice.

${ }^{20}$ Mighty Solutions CC t/a Orlando Service Station v. Engen Petroleum Ltd., 2015 ZACC 34 per Van der Westhuizen J. at para 36.

${ }^{21}$ Per Prof. Patrick O'Brien Faculty of Law Brochure at http://www.uj.ac.za/EN/Faculties/law/application/documents/UJ\%20faculty\%20brochure.pdf (last visited May15, 2016). The University of Johannesburg has an interesting slogan of in respect of its teaching ethos which is to teach "students to be" as opposed to merely teaching students "to know". On the website the Faculty of Law states, inter alia, that "The UJ Faculty of Law aims to produce well-rounded, skilled and knowledgeable graduates who will indeed be able to participate meaningfully and effectively in current legal and policy debate, and who will make a positive contribution to the legal profession and other spheres of our democratic society-at www.uj.ac.za/faculties/law/Pages/About/-Us.aspx (last visited May 15, 2016). 22 of 1996.

${ }^{23}$ The success of the South African constitutional dispensation depends on the active participation of government, legal profession, universities, the media, civil society and even churches. See Van der Westhuizen J., A Few Reflections on the Role of Courts, Government, the Legal Profession, Universities, the Media and Civil Society in a Constitutional Democracy, 8 AFRICAN HUMAN RIGHTS Journal 251 (2008); and Vorster J., Managing Corruption in South Africa: The Ethical Responsibility of Churches, 109 SCRIPTURA 133 (2012). For purposes of this article, so as not to dilute the focus of the thesis, emphasis is placed on the role to be played by future legal practitioners.
} 
However, this norm must be combined with a purposive interpretation. One which seeks to tease out the values underlying an open and democratic society based on human dignity, equality and freedom inclusive of a promotion of the sprit, purport and objects of the Bill of Rights. ${ }^{24}$ Such interpretations must conduce and translate into transforming South African to a "democratic, participatory and egalitarian" 25 society by means of transformative constitutionalism. The latter notion as coined and popularized by Karl Klare has since preoccupied constitutional jurisprudence with felicitous debate. ${ }^{26}$ In other words, the provisions of the Bill of Rights would remain meaningless unless making the aspirations therein contained realizable for ordinary citizens. ${ }^{27}$ In addition, our courts

\footnotetext{
${ }^{24}$ See section 39(1) \& (2) of the Constitution which imposes this duty of interpretation on a court, tribunal or forum when interpreting the Bill of Rights. For further reading see Minister of Safety and Security \& Others: In re Ex Parte Walters 2002 (4) SA 613 (CC) para 21 and authorities cited at ftn 30; Guest S., The Role of Moral Equality in Legal Argument in THE PRACTICE OF INTEGRITY: REFLECTIONS ON RONALD Dworkin \& South African LaW 18 (Du Bois F. ed. Cape Town: Juta 2008); S v. Zuma 1995 (2) SA 642 (CC) par 15; S v. Makwanyane 1995 (3) SA 391 (CC) par 10; Raban O., Dworkin's "Best Light" Requirement and the Proper Methodology of Legal Theory, 23(2) OXFORD JOURNAL OF LEGAL STUDIES 243-245 (2003); Roux T., The Politics of PrinciPle: The First South AFrican Constitutional Court 278 (Sydney: Cambridge University Press 2013); and Botha H. \& VAN DER WALt J., Rights AND DemoCRACY In A TRANSFORMative Constitution 114 (Stellenbosch: Sun Press (2003).

${ }^{25}$ Klare K., Legal Culture and Transformative Constitutionalism, 150 (1998).

${ }^{26}$ Corder H. \& Federico V., The Quest for Constitutionalism: South Africa Since 1994, 84 (2016); Van Marle K., Revisiting the Politics of Post-Apartheid Constitutional Interpretation, 2 TSAR 549 (2003); Van der Walt J., Legal History, Legal Culture and Transformation in a Constitutional Democracy, 1 Fundamina 1 (2006); Van Marle K., Laughter, Refusal, Friendship: Thoughts on a "Jurisprudence of Generosity", 18(1) STELL LR 194 (2007); and Le Roux W., Bridges, Clearings and Labyrinths : The Architectural Framing of Post-Apartheid Constitutionalism in PosTApartheid Fragments: Law, Politics \& Critique 59 (Le Roux W. \& Van Marle K. eds. Pretoria: Pretoria University Press 2007).

${ }^{27}$ Currie I. \& De WaAl J., The Bill of Rights Handbook 150 (5th ed. Cape Town: Juta 2005); Meyerson D., JURISPRUDENCE 139-141 (Australia: Oxford University Press 2011); ACKERMANN L., Human Dignity: A Lodestar for EQuality in South Africa 24 (Cape Town: Juta 2013); Du Plessis L., The Status and Role of Legislation in South Africa as a Constitutional Democracy: Some Explanatory Observations, 14(4) PER 94 (2011); O' Regan K., Text Matters: Some Reflections on the Forging of a Constitutional Jurisprudence in South Africa, 75(1) THE MODERn LAW REvIEW 1-72 (2012); Klare K., Legal Culture and Transformative Constitutionalism, 146-171 (1998); Cooke R., The Road Ahead for the Common Law in TOM Bingham AND THE TRANSFORMATION OF THE LAW: A Liber AMICORUM 687-691 (Andenas M. \& Fairgrieve D. eds. 2nd ed. Oxford: Oxfrod University Press 2011); Bilchitz D. \& Williams A., Religion and the Public Sphere: Towards a Model that Positively Recognises Diversity, 25 SAJHR 146-159 (2012); Investigating Directorate: Serious Economic Offences v. Hyundai Motor Distributors 2001 (1) SA 545 (CC); Bishop M. \& Brickhill J., In the Beginning Was the Word: The Role of the Text in the Interpretation of Statutes, 129 SALJ 681-711 (2012); Wallis M., What's in a Word? Interpretation through the Eyes of Ordinary Readers, 127 SALJ 673 - 690 (2010); Budlender G., Transforming the Judiciary: The Politics of the Judiciary in a Democratic South Africa, 4 SALJ 715-718 (2005); Henrico R., Understanding the Concept of "Religion" within the Constitutional Guarantee of Religious Freedom, 4 TSAR 784-803 (2015); and Henrico R., Re-Visiting the Rule of Law and the Principle of Legality: Judicial Nuisance or Licence, 4 TSAR 742 (2014).
} 
are enjoined not to interpret in accordance with moral or philosophically charged convictions but rather value-based judgments that are principled and grounded upon integrity. ${ }^{28}$

A further injunction of interpretation pertains to indigenous law. It is recognized by the Constitution as part of South African $\operatorname{law}^{29}$ which our courts must align with the common law. ${ }^{30}$ The Zulu proverb umuntu ngumuntu ngabantu "a person is a person because of people" (ubuntu) ${ }^{31}$ has been pointed out as encapsulating a "sense of community and interdependence of the members of a community". ${ }^{32}$ More particularly, ubuntu or the obligation to care for family members and the sense of community responsibility - is "[a] vital and fundamental value in [the] African social system" recognised in the African Charter on Human and Peoples' Rights (the Charter). ${ }^{33}$ Inexorably linked to ubuntu, as stated in $\mathrm{S} \mathrm{v}$. Makwanyane, ${ }^{34}$ are notions of respect for life and human dignity. Ubuntu was earmarked in Makwanyane as "permeating the Constitution generally $\ldots$ and specifically fundamental human rights". ${ }^{35}$ Madala J. observed that:

In contrast to the apartheid legal order $\ldots$ the post-apartheid order of constitutionalism requires courts to develop and interpret entrenched rights in terms of a cohesive set of values, ideal to an open and democratic society... ${ }^{36}$

\footnotetext{
${ }^{28}$ MeYerson D., Rights Limited xxvi-xxvii (2013) when referring to the decisions of S v. Makwanyane 1995 (3) SA 391 (CC) para 206; and S v. Zuma 1995 (2) SA 642 (CC) para 18 in which one is reminded of the fact that the constitution as a legal instrument must be interpreted as a legal instrument and not in accordance merely with the personal convictions of the judge.

${ }^{29}$ Bhe \& Others v. Khayelitsha Magistrate \& Others 2005 (1) SA 580 (CC) para 148.

${ }^{30}$ Alexkor Ltd \& Another v. Richterveld Community \& Others 2003 (12) BCLR 1301 (CC) paras 56 and s 39(3) of the Constitution.

${ }^{31}$ As referred to by Langa J. in MEC for Education: KwaZulu Natal \& Other v. Pillay 2008 (1) SA 474 (CC) para 53 who, it is submitted by necessary inference aligned the concept "we are not islands unto ourselves" with the more familiar notion coined by John Donne that "No man is an island." as appears in his 1624 poem Devotions Upon Emergent Occasions and Several Steps in My Sickness Meditation XVII.

${ }^{32}$ Per Ngcobo J. in Bhe para 163; Also see the interesting argument referred to in B. Winks, A Covenant of Compassion: African Humanism and the Rights of Solidarity in the African Charter on Human and Peoples' Rights, 11 African Human Rights LaW Journal 447-452 (2011) in which authors Cornell and Muvangua contend that $u$ buntu includes a social bond whereby through an "engagement and support of others ... we are able to realise a true individuality and rise above our biological distinctiveness into a fully developed person whose uniqueness is inseparable from the journey to moral and ethical development".

${ }^{33}$ Per Ngcobo J. in Bhe para 166. The Charter, also known as the Banjul Charter was adopted in Nairobi on 27 June 1981 which came into effect on 21 October 1986 is an international human rights instrument that was duly signed and ratified by South Africa on 09 July 1996.

3419953 SA 391 (CC).

${ }^{35}$ Para 237.

${ }^{36}$ Para 306.
} 
Ubuntu is integral to transformative constitutionalism. ${ }^{37}$ There can be no doubt that ubuntu gives imputes to transformative constitutionalism in that it demands one to have regard to the imperatives of the Bill of Rights addressing the advancement of the sense of community and social cohesiveness-notions axiomatic to the success of a democratic order. Mokgoro $^{38}$ makes the point that it behoves all responsible role-players in South Africa, "not the least lawyers from all walks of life" ${ }^{39}$ to take responsibility to ensure that the values of the Constitution are not merely empty and hollow words and sentences that appear in writing in the Bill of Rights, but are "swung into action" or "activated" though "creative law reform programmes, methods, approaches and strategies that will enhance adaptation" to aligning our society with the precepts of the values and principles of the Bill of Rights. The greater the number of sources informing the subject matter, the greater the chances of developing a more matured and reflective view enriched by a wealth and depth of insight. ${ }^{40}$ This is in kilter with the view expressed by Aristotle that: "The ultimate goal of education is to assist human beings in developing their unique capacity to contemplate the world and their role in it". ${ }^{41}$ In this sense, future legal practitioners are charged with acknowledging that there is more to the Bill of Rights than the mere didactic criteria they establish.

TLE is a notion that was eruditely captured and articulated by Quinot in 2012. ${ }^{42}$ TLE was predicated on a three-legged theoretical paradigm. First, transformative constitutionalism, which would address the transformation of our society, would be underpinned by a second leg of constructivism which refers to the manner in which a student learns, namely through a process of assimilation of knowledge. The third leg focused on the material impact of digitalization on the process of learning skills and development. Due recognition must of course be given to the value TLE can bring to legal education as formulated by Quinot. This article, seeks to advance the thesis

\footnotetext{
${ }^{37}$ For further reading Himonga C., Taylor M. \& Pope A., Reflection on Judicial Views of Ubuntu, PER 67, 69 (2013); Metz T., Ubuntu as a Moral Theory and Human Rights in South Africa, 11 African Human Rights Journal 532, 540-542 (2011); Schoeman M., A Philosophical View of Social through Restorative Justice Teachings-A Case Study of Traditional Leaders in Ixopo, South Africa, 13(2) Phronimon Volume 19-21 (2012).

${ }^{38}$ A judge of the Constitutional Court from 1994-2009.

${ }^{39}$ Ubuntu and the Law in South Africa, PER 1 (1998).

${ }^{40}$ Hoexter C., Chief Justice Langa and the Importance of Dissent - a paper delivered at the Acta Juridica conference on 16 and 17 January 2014 in honour of the late former chief justice, Pius Langa; and Langa P., The Emperor's New Clothes: Bram Fischer and the Need for Dissent, 23 SAJHR 362 (2007).

${ }^{41}$ Johnson T. \& Reed R., Philosophical Documents in Education 35 (4th ed. England: Pearson Education Ltd 2008).

${ }^{42}$ Quinot G., Transformative Legal Education, 129 SALJ 411-414 (2012).
} 
that TLE is an approach that should be adopted in educating legal practitioners together with a suffusion of the notion of ubuntu in the realization of social justice in South Africa. Tertiary legal education must transcend the narrow confines of the rudimentary black-letter of law essentially for law to be capable of serve a greater purpose, namely the realization of social justice. The imperative is to implement the tenets of transformative constitutionalism to bring about a change in the life of others in accordance with the values and ethos our Constitution embraces. The overall objective to which this conspires is the achievement of social justice, namely a dispensation in which we as a society are able to transcend the legal barriers of equality to effectively protect and advance social and economic equality. ${ }^{43}$ In addition, it underscores an additional role played by education of future practitioners, namely the ability to take guardianship of public office. Central to the responsibilities of such office is an ethos of integrity. This would guarantee that actions, decisions and the exercise of power are value based and principled. ${ }^{44}$ In adopting an approach of TLE suffused with ubuntu students are not simply being educated to know the normative principles of law. They are being sensitized about the need for change, making a difference and being responsible future professionals or stewards of public office.

Various methods can and should be employed to support the necessary pedagogy of professional legal education and the manner in which modules are presented. As previously stated, no universal method of lecturing has been earmarked as being the universal pattern of legal pedagogy. In similar vein, an approach of TLE suffused with ubuntu is proposed as a manner in which social justice can be realized, as made apparent in the case examples

\footnotetext{
${ }^{43}$ Vorster J., Managing Corruption in South Africa: The Ethical Responsibility of Churches, 109 SCRIPTURA 133-144 (2012); Calmon J., Chasing the Wind; Pursuing Social Justice, Overcoming Legal Mis-education and Engaging in Re-socialisation, 37 LAL REVIEW 1167 (2003); Mlambo J., paper delivered entitled The Pursuit of Meaningful Social Justice, 6-7, at www.bla.org.za/documents.media_statements/judge\%20Mhlambo\%20LSNP\%20AGM.pdf (last visited May20, 2016) and Lustbader P., Walk the Talk: Creative Learning Communities, the Promotion and Pedagogy of Social Justice, 4 SeAtTle Journal of Social Sciences 613-624 (2006).

${ }^{44}$ Rosen M., Dignity Its History And MeAning 140-141 (USA: Library of Congress 2012); Rapatsa M., Transformative Constitutionalism in South Africa: 20 Years of Democracy, 5 Mediterranean Journal of Social Sciences 887-893 (2014); Haule R., Some Reflections on the Foundation of Human Rights-Are Human Rights an Alternative to Moral Values?, Max Planck University Year Book 367_381 (2006), at www.mpil.de/files/pdf3/08_romuald1.pdf (last visited May 22, 2016). Guest S., The Role of Moral Equality in Legal Argument in THE PRACTICE OF INTEGRITY REFLECTIONS ON RoNALD DwORKIN \& SOUTH AFrICAN LAw 18, 31-43 (Du Bois F. ed. Cape Town: Juta 2008). Eighteenth century philosopher David Hume popularised the distinction between factual and moral observations. See also MEYERSON D., JURISPRUDENCE 70 (2011); and Schmidt DAvid, Hume: ReAson In History (United States: Pennsylvania Press 2003).
} 
used below. This is not to suggest that this approach is the elixir of methodologies to be employed with legal education. To the extent that it serves to demonstrate the realization of social justice and duties imposed on candidates of public office, it is an approach which has more to offer in terms of benefits than disadvantages.

\section{EARMARKing Legal Practitioners as Potential CANDidATES FOR PUBLIC OFFICE}

Not all legal practitioners find themselves pursuing professional paths in the private sector. Providence often provides that the incumbent of a particular public office is an erstwhile legal practitioner drawn either from the private or public sector. Admission into practice as an attorney requires compliance with certain mandatory degree qualifications, ${ }^{45}$ and an express averment that the applicant is a fit and proper person. ${ }^{46}$ The admission into practice as an advocate also requires compliance with mandatory degree qualifications ${ }^{47}$ and an express averment that the person to be admitted is a fit and proper person. ${ }^{48}$ Common to both admissions is that the candidate is a "fit and proper person". This should not strike one as alarming since a legal practitioner, once admitted is an officer of the court who has an overarching duty to the court in the interests of advancing the administration of justice. ${ }^{49}$ Second to such duty is to jealously protect and advance the interests of the client within the bounds of what professional legal ethics. ${ }^{50}$ A myriad of interpretations can be attached to the term "fit and proper

\footnotetext{
${ }^{45}$ In terms of s 2 of the Attorneys Act 53 of 1979 (the Act).

${ }^{46} \mathrm{~S} 4(\mathrm{~b})$ of the Act.

${ }^{47}$ In terms of s 3(2)(aa) of the Admission of Advocates Act 74 of 1964 (Advocates Act).

${ }^{48} \mathrm{~S} 3(1)$ of the Advocates Act. Advocates in the main first do pupillage with an existing member of the one of the Councils of the Bar, which is a division of the General Bar Council. Upon successful completion of a 12 month period of pupillage and the Bar Examination they are permitted to become members of a particular Bar Council and take up chambers. There is also what is known as the "Independent Bar". This latter organisation is unregulated and although consisting of advocates who have been admitted, they are not members of any Bar Council. The 'Independent Bar' is generally frowned upon in the mainstream legal profession due to their official lack of general governance and compliance with, inter alia, the Uniform Rules of Professional Conduct which bind all members of the General Council of the Bar at www.sabar.co.za/GCB-UniformRules-of-Ethics-updatedJuly2012pdf (last visited May 17, 2016).

${ }^{49}$ Holness D., Recent Developments in the Provision of Pro Bono Legal Services by Attorneys in South Africa, PER 127-45 (2013); and Tavangu V., Balancing a Duty to the Court and to the Client: A Dilemma of Legal Practice in Tanzania, 4 OPEN University LAW JOURNAL 147-149 (2013). ${ }^{50}$ Slabbert M., The Requirement of Being a "Fit and Proper" Person for the Legal Profession, PER 208, 216-217 (2011); and Van der Westhuizen J., A Few Reflections on the Role of Courts, Government, the Legal Profession, Universities, the Media and Civil Society in a Constitutional Democracy, 8(1) African Human Rights Journal 251, 265-266 (2008).
} 
person". The minimum threshold must surely be that the individual is a person of integrity. The etymology of the word "integrity" is the noun integritas ${ }^{51}$ for soundness or integer for whole or complete. ${ }^{52}$ Put differently, doing something with integrity is to execute a task or responsibility with completeness or wholeness. In the context of the premise of the thesis advanced herein, integrity on the part of the legal practitioner would mean the performance of her professional duties in a manner that is beyond reproach.

Public office as an entity is not defined in South Africa. An organ of state is, however, defined in the Constitution as meaning:

(a) Any department of state or administration in the national, provincial or local sphere of government; or

(b) Any other functionary or institution

(i) Exercising a power or performing a function in terms of the Constitution or a provincial constitution; or

(ii) Exercising a public power or performing a public function in terms of any legislation ....

Inclusion in the above of the word "functionary" and the terms "exercising a public power or performing a public function" has come to mean that not only governmental entities are subject to judicial review but also private entities, to the extent that the power exercised constitutes a public power impacting upon individual interests. ${ }^{54}$ As can be seen from Allpay Consolidated Investment Holdings (Pty) Ltd \& Others v. Chief Executive Officer of the South African Social Security Agency \& Others (No 2) ${ }^{55}$ constitutional obligations are capable of being imposed upon corporate entities, and by implication the office bearers of such entities. ${ }^{56}$ More specifically, when viewing the function of public office in relation to executive and judicial duties certain prescripts of the Constitution are notable. All spheres of government must: Secure the well-being of the

\footnotetext{
${ }^{51}$ Simpson D., Cassell's Latin Dictionary 301 (4th ed. London: Cassell \& Co 1966).

${ }^{52}$ Pearsall J., Concise OXford Dictionary 755 (10th ed. Oxford: Oxford University Press 2002).

${ }^{53}$ S 239.

${ }^{54}$ For further reading see, Dawnlaan Beleggings (Edms) Bpk v. Johannesburg Stock Exchange \& Others 1983 (3) SA 344 (W) para 31; AAA Investments (Pty) Ltd v. Micro Regulatory Council \& Another 2007 (1) SA 343 (CC) para 39; and Calibre Clinical Consultants (Pty) Ltd \& Another v. National Bargaining Council for the Road Freight Industry \& Another 2010 (5) SA 457 (SCA) para 33.

552014 (4) SA 179 (CC).

${ }^{56}$ This would be in addition to contractual or fiduciary duties arising from any corporate-based obligations. See, for example J. van Tonder "An analysis of the directors" duty to act in the best interests of the company, through the lens of the business judgment rule 36(3) OBITER 702, 705709 (2015)
} 
people of the Republic $;{ }^{57}$ be loyal to the Constitution, the Republic and its people ${ }^{58}$ not assume any power or function except those conferred on them in terms of the Constitution. ${ }^{59}$ In addition, before members of the Executive Council or a province begin to perform their functions, they must swear or affirm faithfulness to the Republic and obedience to the Constitution. ${ }^{60}$ The President, as Head of State, and head of the national executive, must uphold, defend and respect the Constitution as the supreme law of the Republic. ${ }^{61}$ The courts are independent and subject only to the Constitution and the law, which they must apply without fear favour or prejudice. ${ }^{62}$

Policing the enforcement and observation of the constitutional obligations imposed on the holders of public office effectively takes place through the mechanism of the South African State Institutions Supporting Democracy. ${ }^{63}$ They are, for example the South African Human Rights Commission, ${ }^{64}$ the Commission for Gender Equality ${ }^{65}$ and the Public Protector ${ }^{66}$ In South African Broadcasting Corporation \& Others v. DA \& Others ${ }^{67}$ the court pointed out that "in constitutional democracies, public administrators and State institutions are guardians of the public weal". ${ }^{68}$ This was affirmed recently in Economic Freedom Fighters v. Speaker of the National Assembly \& Others ${ }^{69}$ (the EFF case). The office of the public protector was designated, in a constitutional democracy, as being the appropriate entity to ensure "governmental accountability" of serving the public interest ${ }^{71}$ and with particular focus upon the "objective of policing State officials to guard against corruption ${ }^{72}$ and malfeasance in

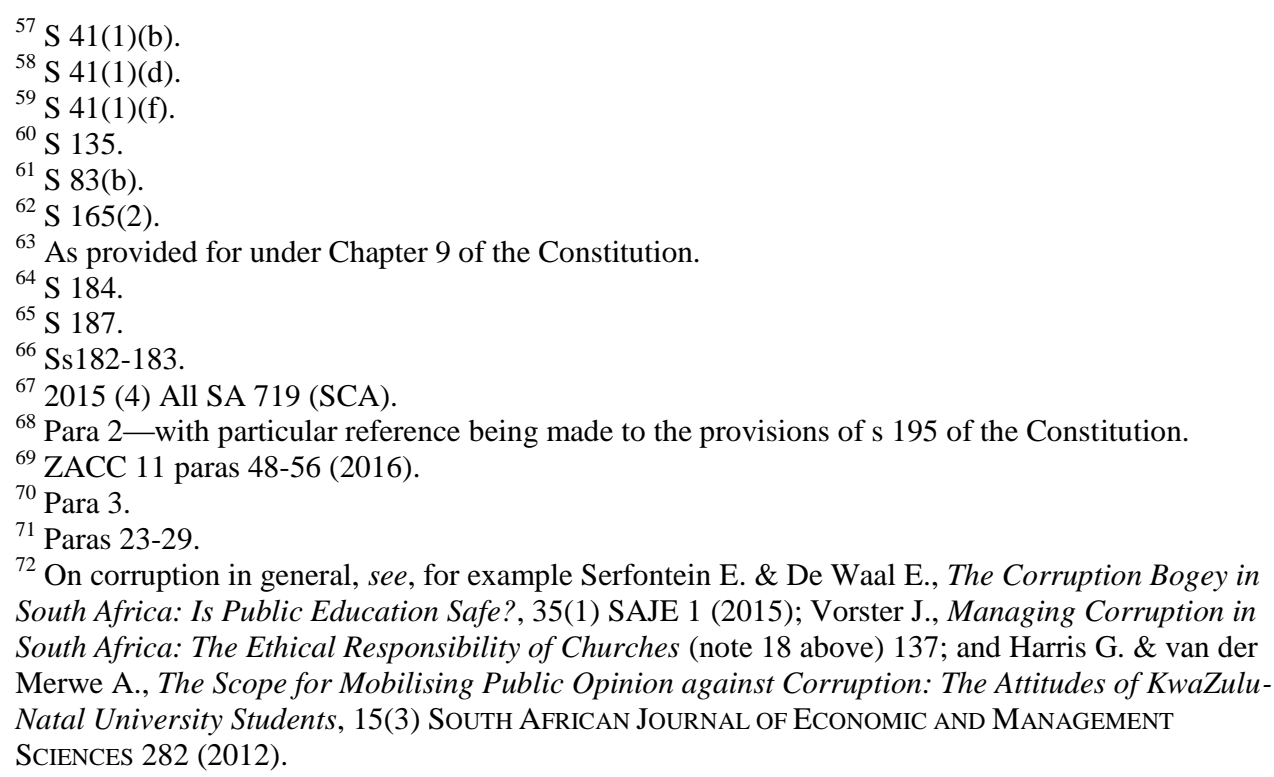


public office ...". ${ }^{73}$ The allegations raised by the Public Protector surrounding President Jacob Zuma's Nkandla homestead ${ }^{74}$ placed South Africa in the media spotlight and called into question the integrity of the President. ${ }^{75}$ This very fact aligns itself inexorably with the demanding role to be played by TLE as an approach in the education of future legal practitioners and awareness of their role in society, alternatively the role they may assume as public office bearers.

\section{AdMINISTRATIVE LAW AS AN EXAMPLE}

South African administrative law occupies a noteworthy place in our jurisprudence. Teaching administrative law to students before the constitutional dispensation in South Africa was a restrictive exercise. In the main one was confined to what one could not do. In a system of Parliamentary sovereignty the review powers of the courts were severely curtailed. ${ }^{76}$ Academics and human rights objectors bemoaned the unconscionable incursion by the executive on basic human rights. Without the effective power of judicial review for the courts to act as watchdog against the excesses of power on the part of the legislature and executive, administrative law was appositely described as a "depressing era" 77 of our law. Any endeavors in legal education to advance administrative justice were diluted by the reality of a rigid and hostile political system which saw little or no appreciable advancement or development of human rights or social justice.

With the coming into operation of the final Constitution, the Bill of Rights expressly guaranteed the right to just administrative action in providing that "Everyone has the right to administrative action that is lawful,

\footnotetext{
${ }^{73}$ Para 44.

74 "Madonsela seeks invitation to Nkandla debate" Cape Times (1 April 2014) and Hamil J., Zuma's Scandals Threaten ANC, South Africa with "lost decade" World Politics Review November 5, 2014 at www.worldpoliticsreview.com/articles/14361 (last visited May 20, 2016).

${ }^{75}$ Presence Ferreira \& Davies, Nkandla Report Passes after Riotous Debate, News24 (November 13, 2014); Prinsloo, "Nkandalgate" - A Critical Textual Analysis of the Press Coverage, The Media Policy and Democracy Project at www.mediaanddemocracy.com/uploads/1/6//5/7/16577624.pdf (last visited May 22, 2016) and Evans, Judgment Reserved in Nkandla Concourt Application, MAIL \& GUARDIAN (February 10, 2016). See the $E F F$ case and findings made against President Zuma in para 83.

${ }^{76}$ Quinot G., Administrative Justice in South Africa: An Introduction 14-15 (South Africa: Oxford University Press 2015); generally Dugard J., Human RightS AND THE SOUTH AFRICAN Legal ORDER (1978); and Elman S., In A Time of Trouble LAW AND LiberTy IN THE SOUTH AFRICA's STATE OF EMERGENCY (Oxford: Oxford University Press 1992).

${ }^{77}$ HoeXter C., Administrative Law in South Africa 267 (2nd ed. Cape Town: Juta 2012).
} 
reasonable and procedurally fair". ${ }^{78}$ Since the aforesaid constitutional provision is not self-executing, meaning that one cannot rely directly thereon, the drafters of the Constitution provided that national legislation must be enacted to give effect to the right to administrative action. ${ }^{79}$ The national legislation that came into effect in this regard is the Promotion of Administrative Justice Act ${ }^{80}$ (PAJA). In order to give effect to the Constitution, the interpretation of the PAJA is one which generously favours rights as opposed to their restrictive interpretation. ${ }^{81}$ In addition, as with the interpretation of all legislation, PAJA must be interpreted consistent with the provisions of section 39(2) of the Constitution by promoting the spirit, purport and objects of the Bill of Rights. ${ }^{82}$

Human rights imperatives, including but not limited to values and norms, are not unique to administrative law. They have relevance to all law. The horizontal and vertical application of the Constitution ${ }^{83}$ permits the Bill of Rights to extend its reach into the realm of private law. ${ }^{84}$ The postconstitutional dispensation translated into a seismic shift for administrative law. This meant that potential possibilities and opportunities now existed to use administrative law as a tool with a view to achieving administrative justice which would serve as a form of transformative justice. The fact that

\footnotetext{
${ }^{78} \mathrm{~S} 33(1)$; Sub-s (2) makes provision for everyone whose rights have been adversely affected by administrative action to be given written reasons.

${ }^{79}$ In terms of s 33(3).

${ }^{80} 3$ of 2000 which came into operation on 30 November 2000. Until the coming into operation of PAJA, administrative action matters were adjudicated with reference to the provision of Schedule 6, Item 23 (b) (the Schedule). Essentially this meant that when adjudicating administrative action matters, courts were entitled to use as a frame of reference the provisions of paragraphs (a)-(d) as contained in the Schedule and in particular when considering the basis for reviewing an administrative action enquiring whether same was justifiable in relation to the reasons given for it where any of the rights of the applicant or claimant were affected.

${ }^{81}$ See Currie I., The Promotion of Administrative Justice Act: A Commentary 27 (2nd ed Cape Town: Siber Ink 2007) and the authorities cited at fn 5.

${ }^{82}$ Bennion F., StATUtory InTERPRETAtion 520 (4th ed. Australia: LexisNexis 2002); and Carmichele v. Minister of Safety and Security 2001 (4) SA 938 (CC) para 33 and Venter F., Fundamental Rights in SOUTH Africa: AN INTROduction 14-20 (2015); and Mighty Solutions CC t/a Orlando Service Station v. Engen Petroleum Ltd. 2015 ZACC 34 per Van der Westhuizen J. at para 36.

${ }^{83}$ In terms of s 8(2) which states that: "A provision of the Bill of Rights binds a natural or a juristic person if, and to the extent that, it is applicable, taking into account the nature of the right and the nature of any duty imposed by the right".

${ }^{84}$ See, for example Barkhuizen v. Napier 2007 (5) SA 323 (CC) para 57 where the court made it clear the enforceability of a restraint of trade and doctrine of pacta sunt servanda were enforceable provided they did not conflict with constitutional values; and Mozart Ice Cream Franchises (Pty) Ltd. v. Davidoff 2009 (3) SA 78 (C) par 20 and Carmichele v. Minister of Safety and Security 2001 (4) SA 938 (CC) para 58-59 in which the applicant instituted a claim for delictual damages against the Minister and the court commented upon the far-reaching implications of constitutional obligations arising from private law delictual duties.
} 
administrative law could now serve as a catalyst for transformation in the South African constitutional dispensation was singled out by the constitutional court in Pharmaceutical Manufacturers Association of South Africa \& Another; In Re Ex Parte Application of the president of the Republic of South Africa ${ }^{85}$ when Chaskalson P stated that:

Whilst there is no bright line between public and private law, administrative law, which forms the core of public law, occupies a special place in our jurisprudence. ${ }^{86}$

Moreover, as evidenced by the cases studied in this article, the dispensing of administrative justice served, and continues to serve, the purpose of transformative constitutionalism and the realization of social justice.

PAJA is a short piece of legislation. ${ }^{87}$ It has been criticized for its convoluted definition of administrative action: ${ }^{88}$ Something which has been described as "unwieldy" ${ }^{89}$ The fact that PAJA also contains a lengthy list of listed grounds ${ }^{90}$ excluded from the definition of administrative action has resulted in it being referred to as containing a "palisade of qualifications". 91 Powers not falling under the remit of the definition of PAJA essentially escape judicial review. As a result, a need was thus created for a means of holding the exercise of all power ${ }^{92}$ which impacted adversely upon the rights and interests of an individual, subject to judicial review, on the basis that for power to be lawful it must at the very least be legitimate.

Accordingly, the principle of legality was introduced into South African administrative law $^{93}$ as an additional means of holding accountable, and subject to review, the exercise of all power, even if the power was not

\footnotetext{
2000 (2) SA 674 (CC).

${ }^{86}$ Paras 44-45.

${ }^{87}$ Consisting of a mere ten sections.

${ }^{88}$ Appearing in $\mathrm{s} 1$.

${ }^{89}$ Minister of Defence Military Veterans v. Motau \& Others 2014 (5) SA 69 (CC) par 33.

${ }^{90}$ Executive, constitutional or judicial in nature.

${ }^{91}$ Per Nugent JA in Grey's Marine Hout Bay (Pty) Ltd v. Minister of Public Works 2005 (6) SA 313 (SCA) para 21; also see criticism against the PAJA at para 22; Hoexter C., "Administrative Action" in the Courts, ACTA JURIDICA 303-306 (2006); Currie I., What Difference does the Promotion of Administrative Justice Act Make to Administrative Law?, ACTA JURIDICA 325-347 (2006); and the critique against the provisions of the PAJA by Hoexter C., The Principle of Legality in South African Administrative Law, 4 MACQUARIE LAW JOURNAL 165, 177-179 (2004).

${ }_{92}$ Whether public or private. See AAA Investments (Pty) Ltd. v. Micro Finance Regulatory Council \& Another 2007 (1) SA 343 (CC) para 39; and Dawnlaan Beleggings (Edms) Bpk v. JHB Stock Exchange \& Others 1983 (3) SA 344 (W) para 38.

${ }^{93}$ Fedsure Life Assurance Ltd. v. Greater Johannesburg Transitional Metropolitan Council 1999 (1) SA 374 (CC) para 56.
} 
subject to review under PAJA. ${ }^{94}$ The principle of legality is an incident of the rule of law which is enshrined in the Constitution. ${ }^{95}$ The effect of introducing the principle of legality into South African administrative law was transformative in nature. ${ }^{96}$ The judicial authority of the court to scrutinize the exercise of all power in terms of judicial review is increased effectively rendering the court guardian of the Constitution and the strongest arm of government. ${ }^{97}$ This was strongly emphasized in Pharmaceutical Manufacturers Association of SA when the court stated:

Courts no longer have to claim space and push boundaries to find means of controlling public power. That control is vested in them under the Constitution, which defines the role of the courts, their powers in relation to the other arms of government and the constraints subject to which public power has to be exercised. $^{98}$

The principle of legality grew exponentially in administrative law as an alternative and more flexible way of granting administrative justice relief, as opposed to the rigid and regulatory requirements imposed by PAJA. ${ }^{99}$ It was applied as a more malleable means of granting administrative justice.

\footnotetext{
${ }^{94}$ An obvious exception to judicial review is the issue of separation of powers and the due deference which the judiciary has to the creation of policy on the part of the executive. In other words, the closer the exercise of the function is to the formulation of policy the less likely it is for the judiciary to review, however, once the policy is implemented the further it moves away from the executive domain and the more likely it becomes an administrative action matter subject to judicial review. See Minister of Home Affairs \& Others v. Scalabrini Centre \& Others 2013 (6) SA 421 (SCA) paras 5457; Offit Enterprises (Pty) Ltd v. Coega Development Corporation \& Others 2014 (4) SA 242 (CC) par 43; Pharmaceutical Manufacturers Association of South Africa \& Another: In Re Ex parte President of the Republic of South Africa 2000 (2) SA 674 (CC) para 79; and Hoexter C., The Future of Judicial Review in South African Administrative Law, 117 South African Law Journal 484 (2000); also see s 85(2)(b)-(d) of the Constitution.

${ }^{95} \mathrm{~S} 1$ (c) provides that the Republic of South Africa is one, sovereign, democratic state founded on the supremacy of the constitution and the rule of law.

${ }^{96}$ In as much as it permits the realization of administrative justice for individuals whose rights may be negatively affected as a result of the exercise of all public power or the performance of a public function.

${ }^{97}$ Johannesburg Consolidated Investment Co v. Johannesburg Town Council 1903 TS 111 para 115; Glenister v. President of the Republic of South Africa \& Others 2011 (3) SA 347 (CC); Nkabinde \& Another v. Judicial Service Commission President of the Judicial Conduct Tribunal \& Others 2015 (1) SA 279 (GJ) para 111; and Henrico R., Re-visiting the Rule of Law and Principle of Legality: Judicial Nuisance or Licence?, 759 (2014).

${ }^{98}$ Paras 44-45.

${ }^{99}$ For further reading on the jurisprudential development of the principle of legality see SARFU v. President of the RSA 2000 (1) SA 1 (CC); Masetlha v. President of the RSA 2008 (1) SA 566 (CC); Bato Star Fishing v. Minister of Environmental Affairs \& Others 2004 (4) SA 490 (CC); Albutt v. Centre for the Study of Violence and Reconciliation 2010 (3) SA 293 (CC); Wessels v. Minister for Justice and Constitutional Development 2010 (1) SA 128 (GNP); Democratic Alliance v. Acting National Director of Public Prosecutions 2012 (3) SA 486 (SCA) and Head of Department, Department of Education, Free State Province v. Welcome High School 2014 (2) SA 228 (CC).
} 
TLE suffused with ubuntu highlights the importance of administrative law as a means of using administrative justice to guard against the excesses of public power address the fundamental tenets of transformation in a constitutional democracy. In a dispensation subject to the supremacy of the Constitution and the rule of law it is imperative that students are made aware of the importance of accountability under the rule of law. More particularly, that when power, whether by a public or private entity is exercised, which adversely impacts upon the rights and interests of citizens, such power can be subject to judicial review and be held accountable in terms of the values and principles embraced by the Constitution. This form of education engenders not only awareness but also accountability, responsibility and civic duty.

The two cases focused upon support the thesis of this article, namely that administrative law in general and justice in particular is by its nature is transformative in nature and able to give effect to social justice. As such it is an optimal module by which to educate and train future legal practitioners and potential future public officials. Whilst many cases can be referred to in South African administrative law which support the above contention, ${ }^{100}$ for the sake of brevity, the two cases discussed below do so in the most exemplary fashion.

The first case is Joseph \& Others v. City of Johannesburg \& Others. ${ }^{101}$ This case is one in which there was a clarion call for social justice on the part of the applicants. They were all poor tenants (the tenants) renting monthly accommodation from a landlord (the landlord) in a block of flats, namely Ennerdale Mansions. Each month the tenants paid their electricity bills to the landlord. Electricity was provided to Ennerdale by City Power (Pty) Ltd (the service provider) with whom the landlord had entered into a contract for the provision of monthly electricity (the contract). Unbeknown to the tenants, the landlord failed to pay over the monthly payments received from the tenants in respect of their electricity bills to the service provider and instead pocketed a handsome sum of R400000. As a result, the service provider disconnected the supply of electricity to Ennerdale Mansions. They did so without any notice to the tenants. Notice was only given to the landlord who failed to notify the tenants. After failed attempts to contact the landlord, and in desperation the tenants formed a committee (the committee) who referred their concern about the termination of electricity supply to the

\footnotetext{
${ }^{100}$ For example, see Chirwa v. Transnet Ltd. 2008 (4) SA 367 (CC); Minister of Health v. New Clicks 2006 (2) SA 311 (CC); and Zondi v. MEC for Traditional and Local Government Affairs 2005 (3) SA 589 (CC).

${ }^{101} 20144$ SA 55 (CC).
} 
City Council who in turn referred the committee to social interest groups. ${ }^{102}$ Eventually the tenants approached the High Court on an urgent basis seeking immediate reconnection of their electricity supply. Their application was dismissed. ${ }^{103} \mathrm{~A}$ further application in the High Court in which the applicant's urged for an order declaring the disconnection of the electricity without notice to themselves to be procedurally unfair in terms of PAJA ${ }^{104}$ proved unsuccessful. ${ }^{105}$

On appeal to the Constitutional Court Skweyiya J. observed that the case concerned the interpretation of PAJA which necessarily raised constitutional issues. ${ }^{106}$ The applicant's relief had been opposed on the basis that there had been no contractual nexus between themselves as tenants and the service provider. Skweyiya J., however, rejected such view finding that the matter concerned the relationship between "a public service provider and consumers with whom it has no contractual relationship, and that principles of administrative and constitutional law-and not the law of contractgovern the issues that arise". ${ }^{107}$ In his judgment, Skweyiya J applied the concept of a "special cluster of relationships" 108 in considering the issue of the termination of the supply of electricity by the service provider to the tenants to sustain the view that administrative law principles operate and function to govern relations beyond the narrow confines of the law of contract. Having established a basis upon which administrative law was applicable to the relief sought, the court proceeded to consider the right to procedural fairness under section 3 of PAJA, namely, whether the applicants had been entitled as tenants to receive notice from the service provider before the disconnection of the electricity supply. Against the backdrop of considering civic public responsibilities imposed on service providers such as the respondent ${ }^{109}$ there were also duties imposed on the respondent as a service provider under the Constitution, namely the prioritization of the

\footnotetext{
${ }^{102}$ The South African Human Rights Commission and the Rental Housing Tribunal.

${ }^{103}$ Tsoka J. found that the applicants had failed to establish a prima facie case.

${ }^{104} \mathrm{~S} 3(2)(\mathrm{b})$.

${ }^{105}$ Jajbhay J. found that no constitutional rights of the applicants had been affected by the termination of the electricity.

${ }^{106}$ Para 17, in this regard reference was made to Bato Star Fishing (Pty) Ltd v. Minister of Environmental Affairs \& Tourism \& Others 2004 (4) SA 490 (CC) paras 72-77.

${ }^{107}$ Para 18.

${ }^{108}$ A term coined by Sachs J in Residents of Joe Slovo Community, Western Cape v. Thubelisha Homes \& Others 2010 (3) SA 454 (CC) at para 343 with reference to dealing with the issue of unlawfulness of the occupation of municipal council land by homeless families and the public responsibility on the part of government flowing from the context of such a situation.

${ }^{109}$ In the form of basic amenities such as water and electricity to residents in fulfillment of its duties as local government in terms of s 73 of the Local Government: Municipal Systems Act 32 of 2000 and the Housing Act 107 of 1997; see para 37 of the Joseph case.
} 
basic needs of the community and the promotion of the social and economic development of the community. ${ }^{110}$ These factors resulted in Skweyiya J. finding that the purpose of administrative justice in a constitutional democracy "confirms" the need to interpret the right of the applicants to have received a pre-termination notice from the service provider. The rationale for this finding is supported by the following dicta:

The preamble of PAJA gives expression to the role of administrative justice and provides that the objectives of PAJA are inter alia to 'promote an efficient administration and good governance' and 'to create a culture of accountability, openness and transparency in the public administration or in the exercise of a public power or the performance of a public function'. These objectives give expression to the founding values in section 1 of the Constitution, namely that South Africa is founded on the rule of law and on principles of democratic government to ensure accountability, responsiveness and openness. ${ }^{111}$

The aforesaid reasoning is further reinforced by Skweyiya J.'s observation that local government's compliance with its procedural fairness obligations is crucial not only for the protection of the rights of citizens but to facilitate trust in the public administration in the South African participatory democracy of which Batho Pele forms an essential ingredient. $^{112}$

The imperative of transformative constitutionalism also appears from the judgment in the observation that the right to administrative justice is fundamental to the realization of constitutional values which is at the heart of the transition to a constitutional democracy. ${ }^{113}$

This case is highly relevant as a case study for educating future legal practitioners for the very important issues raised: Issues of awareness of the how administrative justice is given effect to by holding public service providers (local government) accountable to their constituents. More importantly, the social obligations imposed on government are of special importance in the context of enforcing those obligations in favour of the marginalized, the poor, and less privileged members of our society who would not have the financial wherewithal to pursue litigation disputes based on contractual causes of action.

Two imperatives are played out by the case. First, awareness on the part of the legal practitioner of the extent to which administrative law as a discipline of public law can be employed to transcend the normative and

\footnotetext{
${ }^{110} \mathrm{~S} 153$. See para 36 of the Joseph case.

${ }^{111}$ Para 43.

${ }^{112}$ Para 46 and esp. the authorities cited at $\mathrm{ftn} 39$. Batho Pele is discussed in greater detail below.

${ }^{113}$ Para 45
} 
narrow confines of private civil law where little or no relief could be obtained in advancing the interests of a client. Secondly, the obligations imposed on the part of public office ${ }^{114}$ in a constitutional to democracy to give effect to the rule of law ${ }^{115}$ and subject themselves to basic values and principles governing public administration. ${ }^{116}$

The second case is Allpay Consolidated Investment Holdings (Pty) Ltd \& Others v. Chief Executive Officer of the South African Social Security Agency \& Others (No 2) ${ }^{117}$ The Constitutional Court found the tender of a contract (the tender) for the payment of social grants between the South African Social Security Agency (SASSA) and Cash Paymaster Services (Pty) Ltd (CPS) to be constitutionally invalid. ${ }^{118}$ The Court granted an order in terms of which it suspended the declaration of invalidity (of the tender). ${ }^{119}$ This is precisely why the case is so significant because it was the first time the Court granted an order of invalidity ${ }^{120}$ which it suspended, and moreover it included in such order "just and equitable" relief. "121 Additional significance of the case arises from the remedy granted in lieu of the judgment. Paying particular attention to the imperative of constitutional obligations resting on the state, the Constitutional Court observed that "the state must take reasonable legislative and other measures, within its available resources, to achieve the progressive realisation of the right "to social assistance". ${ }^{122}$ Moreover, organs of state, even if not state departments or part of the public administration or various spheres of government ${ }^{123}$ have obligations that "extend beyond the mere contractual"

\footnotetext{
${ }^{114}$ Such as the function of a municipality or local community council.

${ }^{115} \mathrm{~S} 1$ (c) of the Constitution.

${ }^{116}$ These are set out under section 195(1)-(6) of the Constitution. During the presidency of Nelson Mandela, the presidential administration introduced the notion of Batho Pele (a Sotho word meaning "People First") which consisted of eight principles to serve as guidelines for the better delivery of goods and service by government to the public. See Pietersen C., Implementation of Batho Pele Principles in and Educational District Office, 5(3) MediterRanean Journal of Social SCIENCES 253-255 (2014); and Pretorius D. \& Schurink W., Enhancing Service Delivery in Local Government: The Case of a District Municipality, 5(3) SA Journal of Resource MANAGEMEnt 19, 23 (2007). 1172014 (4) SA 179 (CC).

${ }^{118}$ See judgment of court in Allpay Consolidated Investment Holdings (Pty) Ltd \& Others v. Chief Executive Officer, South Africa Social Security Agency \& Others (No 1) 2014 (1) SA 604 (CC) at paras 86-93. Essentially there had been improper and material non-compliance with the requirements of procedural fairness in terms of PAJA resulting in the tender process being found to be unconstitutional and unlawful.

${ }^{119}$ Which it has the power to do in terms of s 172(1)(b)(ii) of the Constitution.

${ }^{120}$ Pending the decision to award a new tender after the tender process had been re-run. See para 78 of Allpay (No 1).

${ }^{121}$ In respect of which counsel for all interested parties had been requested to make submissions to the Court Allpay (No 2) Paras 4-5.

${ }^{122}$ In terms of s 27(2) of the Constitution. See para 47.

${ }^{123}$ National, provincial or local.
} 
to "respect, promote and fulfill the rights in the Bill of Rights" with reference to a "democratic government based on the principles of accountability, responsiveness and openness". ${ }^{124}$

Having found CPS to be an organ of state in terms of the impugned tender ${ }^{125}$ it followed that CPS performed a public function in terms of the Agency $\mathrm{Act}^{126}$ which had been enacted to give effect to the right to social security. Extending the duty imposed upon CPS, the Constitutional Court observed that CPS does more than perform a public function. In terms of the role it played in concluding the type of tender it concluded with SASSA it took on a "unique and central role as gatekeeper of the right to social security and effectively controls beneficiaries' access to social assistance ... [for the purpose of] payment of social grants" and thereby assumed "constitutional obligations". ${ }^{127}$ These constitutional obligations rested on both parties to the unlawful tender, namely SASSA and CPS. Although the tender was irregular and hence unlawful, neither party could simply walk away and divest themselves of their constitutional responsibilities and public accountability - to hold otherwise would result in interruption of the grant of social security and assistance to a large number of beneficiaries who would be immensely prejudiced on account of their impoverishment and their reliance on such grants. ${ }^{128}$ When dealing with the issue of costs, Froneman J. stated:

There are no real winners or losers in the ordinary litigation sense. If there is any winner, one hopes it will be the general public who will gain from adherence to the rule of law and greater transparency and accountability in relation to the payment of social grants. ${ }^{129}$

The court in Allpay demonstrates the judicial sagacity of using the provisions of the Bill of Rights to transcend normative private law obligations and the ordinary non-accountability or non-liability of parties under an invalid contract. Overarching constitutional obligations arising from tender duties imposed on parties under section 172 of the Constitution, as read with other germane legislation, came to be interpreted in favour of the interests of the beneficiaries, namely those who were dependent on social grants and social assistance and who stood to be most gravely prejudiced on account of the finding that the tender process and award was

\footnotetext{
${ }^{124}$ In terms of s 7(2), 1(d) and 195(2)(b) of the Constitution; see paras 49-50.

${ }^{125} \mathrm{On}$ account of it exercising a public power and performing a public function and also based on the authority of AAA Investments.

1269 of 2004.

${ }^{127}$ Paras 55-56.

${ }^{128}$ Paras 68-71.

${ }^{129}$ Para 77.
} 
unlawful and unconstitutional.

As with the Joseph case, Allpay also demonstrates how administrative law as a discipline of public law can provide relief for marginalized persons where relief in terms of private law remedies would not otherwise exist. Moreover, Allpay demonstrates also the extent to which the incumbents of public office, or even those of directors of corporations can be held accountable in terms of the dictates of constitutional values and imperatives.

Both cases are realistic practical examples of transformative constitutionalism taking place and social justice being realized.

\section{CONCLUSION}

Educators of future legal practitioners have an undeniably relevant role to play in providing learning, teaching and guidance in respect of the normative precepts of law. An overarching duty on educators is to ignite awareness of the responsibility on the part of future legal practitioners by employing an approach to legal education that actively engages TLE together with ubuntu for purposes of realizing the achievement of social justice. As future professionals they have a significant and material role to play in contributing to the development and advancement of a meaningful constitutional dispensation in South Africa. The ability to use public law in general and administrative justice in particular is key to advancing the cause of social justice.

TLE runs the risk of being a mere paradigm and effectively being lost in translation if not used effectively and optimally. By this is meant that its effectiveness depends on a purposive interpretation of our sources of law and our Constitution suffused with the necessary values such as the notion of ubuntu which tease out and animate the provisions of the Bill of Rights in a manner that provides protection, relief and benefit to the disadvantaged of our society in our quest to create a more egalitarian dispensation. From the cases examined, marked benefits have been harvested from our constitutional jurisprudence. TLE suffused with ubuntu can and should be employed as an approach in legal education to create awareness of the aforesaid benefits to the extent that they contribute to the realization of social justice. There is a bifurcated dual-success result. First it imparts to our future legal practitioners the importance of assisting less privileged persons and urging the need for change for the better in the life of others. Secondly, it demonstrates the important imperative as future potential public officials that government and public office is and should always be accountable to the rule of law. Acting at all times with the utmost integrity, 
subject to the rule of law and in the furtherance of advancing the interests of the electorate is precisely what is required of public officials for the maintenance of a viable democratic dispensation. 